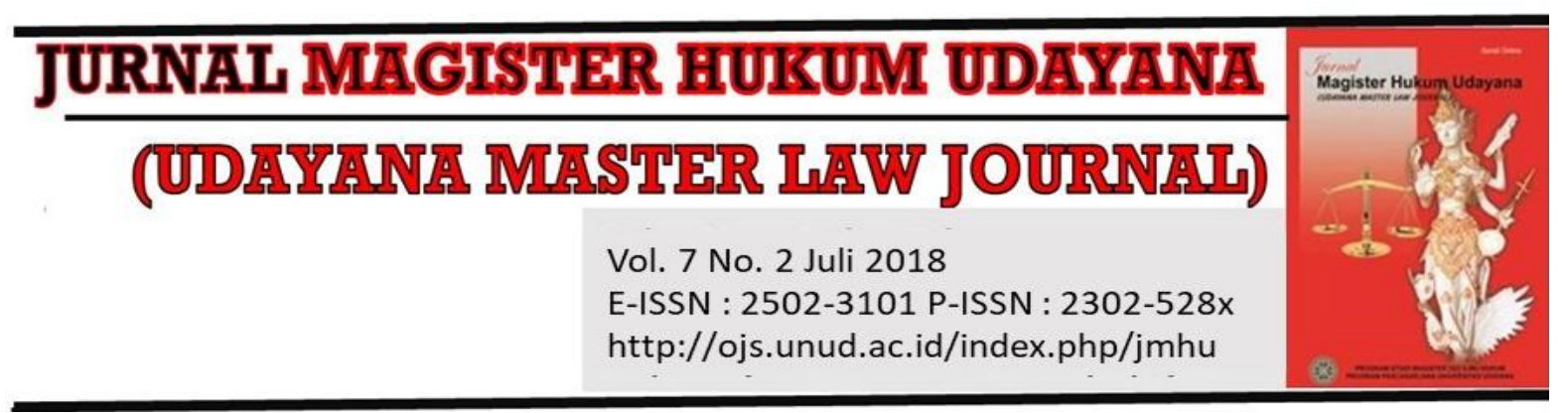

\title{
Pertanggung Jawaban Pidana terhadap Perawat Maternitas yang Menghilangkan Identitas Seorang Bayi di Rumah Sakit
}

\section{Edwina Aileen Wirasasmita ${ }^{1}$}

${ }^{1}$ Fakultas Hukum Universitas Airlangga, E-mail: edwina.aileen@gmail.com

\begin{tabular}{l}
\hline Info Artikel \\
\hline Masuk: 7 Juni 2018 \\
Diterima: 18 Juli 2018 \\
Terbit: 31 Juli 2018 \\
Keywords: \\
Accountability; Nurse; \\
Hospital; Malpractice \\
\\
\\
\\
Kata kunci: \\
Pertanggungjawaban; \\
Perawat; Rumah Sakit; \\
Malpraktek \\
Corresponding Author: \\
Edwina Aileen Wirasasmita, \\
Email: \\
edwina.aileen@gmail.com \\
DOI: \\
10.24843/JMHU.2018.v07.i02 \\
p4
\end{tabular}

\begin{abstract}
Hospitals have their own rules in carrying out the delivery process, the rules contained in the SOPS (Standard Operating Procedures), in the procedure already established procedure for mounting rings for the newborns so the baby cannot be confused with the baby other patients and it is the duty of a maternity nurse. The purpose of this study to analyze the criminal liability for a nurse which resulted in an infant being confused because there is still legal uncertainty regarding what constituted a criminal penalty for someone who makes a person's origins unclear because "one deliberate act" as regulated in Article 277 Criminal Code. Research method uses normative research method by using the Statue approach and the analytical \& Conceptual approach. The study shows that there is criminal responsibility for nurses who deliberately not follow the hospital SOPs while working so that there is a malpractice which resulted in a baby lost his identity as regulated under Article 277 of the Criminal Code
\end{abstract}

\begin{tabular}{l} 
Abstrak \\
\hline Rumah Sakit memiliki peraturannya sendiri dalam melaksanakan \\
proses persalinan, ketentuannya tertuang dalam Standard \\
Operating Procedures, dalam prosedur telah ditetapkan tata cara \\
pemasangan gelang pada bayi baru lahir agar bayi tidak bisa \\
tertukar dengan bayi pasien lain dan merupakan tugas dari \\
perawat maternitas. Tujuan studi ini untuk menganalisis \\
pertanggungjawaban pidana bagi seorang perawat yang \\
mengakibatkan seorang bayi tertukar karena masih terjadi \\
ketidakpastian hukum berkaitan dengan apa yang dimaksud \\
ancaman pidana bagi seseorang yang membuat asal-usul \\
seseorang menjadi tidak jelas karena "salah satu perbuatan \\
sengaja" sebagaimana diatur dalam Pasal 277 KUHP. Metode \\
penelitian menggunakan metode penelitian normatif, dengan \\
pendekatan perundang-undangan dan pendekatan analisa konsep \\
hukum. Hasil studi menunjukkan bahwa pertanggungjawaban \\
secara pidana bagi perawat yang dengan sengaja tidak mengikuti \\
SOP rumah sakit saat bekerja merupakan malpraktik yang \\
mengakibatkan seorang bayi kehilangan identitasnya \\
sebagaimana diatur dalam Pasal 277 KUHP.
\end{tabular}




\section{Pendahuluan}

Secara hukum keberadaan profesi perawat terdapat dalam UU Keperawatan dan UU Tenaga Kesehatan, pengakuan tersebut merupakan dasar seseorang menjadi subjek hukum, subjek hukum atau subject vaan een recht yaitu orang yang mempunyai hak, manusia pribadi atau badan hukum yang berhak, berkehendak atau melakukan perbuatan hukum. Sedangkan perbuatan yang dapat menimbulkan akibat hukum yakni tindakan seseorang berdasarkan suatu ketentuan hukum yang dapat menimbulkan hubungan hukum memberikan dan membebankan hak-hak dan kewajiban-kewajiban pada masing-masing pihak. ${ }^{1}$

Sebagai subjek hukum maka perawat memiliki hak dan kewajiban, Hak merupakan sesuatu yang wajib diterima oleh seseorang karena telah melaksanakan kewajibannya dengan baik. Berdasarkan Pasal 11 Peraturan Menteri Kesehatan Nomor 148 Tahun 2010 Tentang Izin Dan Penyelenggaraan Praktik Perawat, menyatakan bahwa:

"Hak-hak dasar seorang perawat adalah:

a. memperoleh perlindungan hukum dalam melaksanakan praktik keperawatan;

b. memperoleh informasi yang lengkap dan jujur dari klien dan/atau keluarganya;

c. melaksanakan tugas sesuai dengan kompetensinya;

d. menerima imbalan jasa profesi; dan

e. memperoleh jaminan perlindungan terhadap resiko kerja yang berkaitan dengan tugasnya."

Hak-hak tersebut di atas merupakan dasar kewenangan bagi seorang perawat untuk dapat melaksanakan pekerjaannya, seperti kewenangan untuk berhubungan komunikasi dengan pihak-pihak lain baik dengan pasien maupun dengan teman seprofesi. Hubungan hukum antara tenaga kesehatan dengan klien dalam memberikan pertolongan medis disebut juga transaksi terapeutik, yaitu perjanjian antara tenaga kesehatan dan klien berupa hubungan hukum yang melahirkan hak dan kewajiban bagi kedua belah pihak. ${ }^{2}$ Hubungan ini dasarnya adalah kepercayaan klien terhadap tenaga medis sehingga memberikan persetujuan untuk menyembuhkan dengan menerima upaya medis yang dilakukan terhadapnya. "Komunikasi terapeutik, yaitu komunikasi yang singkat, jelas, lengkap dan sederhana, sehingga proses komunikasi dapat berjalan sempurna tidak menimbulkan banyak interpretasi bagi penerima pesan dan isi pesan dapat dipahami secara lengkap." 3 Di sisi lain, Perawat berusaha untuk mengerti dan mencari maksud dari yang disampaikan pasien sehingga mendapatkan inti dari penjelasan yang di sampaikan pasien. ${ }^{4}$ Komunikasi terapeutik merupakan komponen penting dalam keperawatan, komunikasi antar perawat dan pasien memiliki hubungan terapeutik yang bertujuan untuk kesembuhan pasien ${ }^{5}$

\footnotetext{
1 Soedjono, D. (2004). Penghantar Ilmu Hukum. PT Raja Grafindo Persada. Jakarta. h. 128

${ }^{2}$ Masrudi, M. (2016). Etika Profesi dan Hukum Kesehatan.Pustaka Baru Press. Yogyakarta. h. 141

${ }^{3}$ Nugroho, H. W. (2009). Komunikasi Dalam Keperawatan Gerontik. Buku Kedokteran ECG. h.25.

${ }^{4}$ Oktaria, G., \& Awza, R. (2017). Komunikasi Terapeutik Perawat dalam Proses Penyembuhan Pasien Psikosis di Upt. Bina Laras Provinsi Riau. Jurnal Online Mahasiswa Fakultas Ilmu Sosial dan Ilmu Politik Universitas Riau. 4(2). 1-15

${ }^{5}$ Siti, M., Zulpahiyana, Z., \& Indrayana, S. (2016). Komunikasi Terapeutik Perawat Berhubungan dengan Kepuasan Pasien. Jurnal Nurse dan Kebidanan Indonesia. 4(1). 30-34
} 
Komunikasi yang jelas dalam hal menyampaikan informasi yang berkaitan dengan pelayanan kesehatan merupakan salah satu dasar kewajiban seorang perawat pada saat melaksanakan pelayanan kesehatan, kewajiban lainnya yang juga penting adalah kewajiban untuk mematuhi standar-standar yang telah ditetapkan baik oleh pemerintah ataupun oleh instansi tempat seorang perawat bekerja. Komunikasi terapeutik komunikasi yang direncanakan secara sadar, dan bertujuan dan kegiatannya dipusatkan untuk kesembuhan pasien. ${ }^{6}$ Keperawatan maternitas bergerak pada persiapan persalinan serta kualitas pelayanan kesehatan yang dilakukan dan difokuskan kepada kebutuhan fisik klien, dan bayi baru lahir. Perawat maternitas memiliki hubungan kerja dengan rumah sakit, dimana dalam hubungan kerja ini rumah sakit menuntut perawat untuk melaksanakan pelayanan keperawatan sesuai dengan standar prosedur operasional (selanjutnya disebut dengan SPO) yang ditetapkan rumah sakit, bila perawat tidak mengikutinya hingga menimbulkan kerugian bagi pasien dapat dikatakan malpraktek, Malpraktek adalah sikap tindak yang salah, kurang terampil, kurang keterampilan dalam ukuran yang wajar.

Permasalahan pertanggungjawaban pidana terhadap perawat ini muncul karena kekaburan norma dalam Pasal 277 KUHP, Pasal 277 KUHP yaitu “Barangsiapa dengan suatu perbuatan sengaja menggelapkan asal-usul seseorang, diancam karena penggelapan asal-usul, dengan pidana penjara paling lama enam tahun." Menurut Pasal ini seorang yang dengan suatu perbuatan sengaja menggelapkan asal usul seseorang dapat dijatuhi pidana, bagaimana halnya dengan seorang yang perawat yang dengan sengaja tidak mengikuti Standar Prosedur Operasional rumah sakit sehingga mengakibatkan seorang bayi tertukar dengan bayi lainnya, apakah hal ini dapat dikatakan perbuatan sengaja. Adapun menurut R. Soesilo, penjelasan mengenai Pasal 277 KUHP adalah : mengenai "salah satu perbuatan sengaja" adalah Perbuatanperbuatan yang sengaja sehingga asal-usul (kelahiran) seseorang menjadi tidak tentu misalnya anak tertukar, menyembunyikan, memungut, atau suatu keadaan dimana dikatakan seorang anak lahir dari iu yang berbeda dengan ibu sesungguhnya. ${ }^{7}$

\section{Metode Penelitian}

Jenis penelitian dalam penyusunan penulisan ini adalah jenis penelitian normatif, penelitian hukum normatif disebut juga penelitian hukum doktrinal, sering sekali dalam penelitian ini hukum dikonsepkan sebagai apa yang tertulis dalam peraturan perundang-undangan (law in books) atau hukum dikonsepkan sebagai kaidah atau norma yang merupakan patokan berperilaku manusia yang dianggap pantas. ${ }^{8}$ Data utamanya adalah data sekunder berupa bahan hukum dan metode pengumpulan datanya adalah dengan studi kepustakaan/studi dokumen. Pendekatan yang digunakan dalam penelitian ini adalah pendekatan perundang-undangan serta pendekatan analisis konsep.

${ }^{6}$ Yularsih, D. (2014). Penerapan Komunikasi Terapeutik pada Proses Penyembuhan Pasien di Bangsal Keperawatan RSUD Kota Semarang. Jurnal The Messenger. 6(2). 8-16.

7 Soesilo, R. (1996). Kitab Undang-Undang Hukum Pidana Serta Komentar-Komentarnya. Politea. Bogor. h. 202

8 Amirudin, A., \& Asikin, Z. (2010). Pengantar Metode Penelitian Hukum. Rajawali Pers. Jakarta. h. 118 


\section{Hasil dan Pembahasan}

\subsection{Pengaturan Terhadap Profesi Perawat Di Rumah Sakit}

Hubungan antara perawat dan pasien terletak pada saat perawat melakukan pelayanan keperawatan. Pelayanan keperawatan merupakan upaya untuk membantu Pasien baik sakit maupun sehat, dari lahir sampai meninggal dunia dalam bentuk peningkatan pengetahuan dan kemampuan yang dimiliki sehingga individu tersebut dapat melakukan kegiatan sehari-hari secara mandiri, Individu yang dimaksud di atas adalah pasien. ${ }^{9}$ Sedangkan dalam melaksanakan pelayanan keperawatan dikenal dengan istilah asuhan keperawatan. Untuk dapat melaksanakan tugas dan tindakan dengan aman, perawat profesional harus memahami batasan legal dan implikasinya dalam praktik sehari-hari mereka. ${ }^{10}$

Pengaturan tentang Perawat terdapat dalam UU Rumah Sakit yaitu pada bagian kelima Sumber Daya Manusia, tepatnya pada Pasal 12 ayat (1) yang menyatakan bahwa :"Persyaratan sumber daya manusia sebagaimana dimaksud dalam Pasal 7 ayat (1) yaitu Rumah Sakit harus memiliki tenaga tetap yang meliputi tenaga medis dan penunjang medis, tenaga keperawatan, tenaga kefarmasian, tenaga manajemen rumah sakit, dan tenaga non kesehatan."

Menurut Pasal 11 dan Pasal 12 Peraturan Menteri Kesehatan Nomor 49 tahun 2013 tentang Komite Keperawatan Rumah Sakit, Komite Keperawatan di Rumah Sakit memiliki fungsi, tugas dan kewenangan Komite Keperawatan mempunyai fungsi meningkatkan profesionalisme tenaga keperawatan yang bekerja di Rumah Sakit dengan cara: "Melakukan Kredensial (yang dimaksud kredensial ialah, adalah proses evaluasi terhadap tenaga keperawatan untuk menentukan kelayakan pemberian kewenangan klinis) bagi seluruh tenaga keperawatan yang akan melakukan pelayanan keperawatan dan kebidanan di Rumah Sakit."

Pengaturan mengenai Profesi perawat terdapat dalam Undang-Undang Keperawatan khususnya Pasal 1 Ayat (2) yang menyatakan bahwa:"Perawat adalah seseorang yang telah lulus pendidikan keperawatan, di dalam maupun di luar negeri sesuai dengan ketentuan undang-undang."

Mengenai Hak dan Kewajiban Perawat diatur dalam Pasal 36 dan 37 Undang-Undang Keperawatan, di dalamnya telah tertera pada Pasal 37 huruf a dan huruf b yaitu melakukan pelayanan keperawatan sesuai dengan standar prosedur dan peraturan perundang-undangan yang berlaku. Terdapat Peraturan perundang-undangan lain yang juga mengatur mengenai SPO yaitu Pasal 11 Peraturan Menteri Kesehatan Nomor 148 Tahun 2010 Tentang Izin dan Penyelenggaraan Praktik Perawat berisi hak dan kewajiban dasar perawat diatur dalam Keputusan Menteri Kesehatan Nomor 1239 Tahun 2001 yang berkaitan dengan praktik perawat salah satunya ialah mengikuti Standar Prosedur Operasional (SPO) yang berlaku di setiap rumah sakit tempatnya bekerja.

\footnotetext{
${ }^{9}$ Dermawan, D. (2013). Pengantar Keperawatan Profesional. Gosyen Publishing. Yogyakarta. h. 4 ${ }^{10}$ Merdekawati, Y. (2013). Tanggung Jawab Pidana Perawat Dalam Melakukan Tindakan Keperawatan Berdasarkan Undang-Undang Nomor 36 Tahun 2009 Tentang Kesehatan (Studi Di Rumah Sakit Umum Santo Antonius Pontianak). Jurnal Nestor Magister Hukum. 3(5)
} 


\subsection{Pertanggungjawaban Malpraktek Perawat Maternitas Rumah Sakit}

Agar dapat diketahui dapat/tidaknya dimintai pertanggungjawaban pidana maka harus dibuktikan terlebih dahulu ada tidaknya perbuatan pidana/ kesalahan yang diancam menurut hukum pidana.

Terdapat tanggungjawab sebagai perawat maternitas yang berjaga, yaitu harus selalu mengecek kembali (monitoring) rekam medis pasien dan memastikan data yang telah ditulis oleh rekan kerja sebelumnya adalah benar. Jika Perawat Maternitas melakukan atau mengikuti tata cara Prosedur Operasional dengan benar, maka hal bayi tertukar tidak akan dapat terjadi, karena tujuan dari SPO dibuat adalah agar hal-hal seperti demikian tidak dapat terjadi.

Bayi tertukar hanya dapat terjadi apabila:

1. Seorang perawat yang sedang bertugas secara lalai mengisi identitas yang salah pada bayi yang baru lahir atau bayi diberikan jenis gelang yang salah oleh perawat.

2. Perawat maternitas yang memiliki tugas jaga selanjutnya tidak mengikuti prosedur, yaitu melakukan pengecekan ulang terhadap data pada rekam medis dan memperhatikan kecocokan antara isi data tersebut dengan gelang pada bayi dan gelang pada ibu, melainkan langsung pada pengecekan kesehatan secara fisik saja.

Jika benar bahwa hal ini yang dilakukan perawat yang bertugas jaga selanjutnya maka sebagai seorang perawat yang merupakan tugas sehari-harinya mengikuti SPO tidak mungkin tidak mengetahui langkah-langkah yang harus dilaksanakan yang salah satunya adalah melakukan monitoring sesuai SPO karena hal tersebut merupakan kewajiban rutinnya jadi dapat dikatakan seorang perawat sudah mengetahui dengan jelas kewajibannya tetapi ia tetap tidak melaksanakan SPO tersebut, maka dapat dikatakan perawat maternitas bukan lalai namun sengaja tidak melaksanakan SPO tersebut, kesengajaan di sini sesuai dengan pengertian dari teori Kesengajaan, yaitu Kesengajaan dengan Kemungkinan dimana seseorang sudah dapat dikatakan sengaja melakukan suatu hal apabila ketika melakukan suatu hal yang dilarang oleh hukum (tidak mengikuti prosedur dari rumah sakit) dilakukan dengan pengetahuan/ secara sadar dan mengetahui kemungkinan terjadinya akibat dari hal yang dilakukan tersebut tanpa ada usaha mencegah agar perbuatan tersebut tidak dilakukan maka dapat dikatakan bahwa seorang perawat maternitas tidak melakukan asuhan keperawatan sesuai dengan SPO dan akibat dari hal ini adalah terjadinya bayi tertukar. Karena sangat mustahil bayi dapat tertukar apabila seorang perawat melaksanakan SPO sesuai urutan kerja.

Dibawah ini adalah Standar Prosedur Operasional Pemberian Gelang pada Bayi Baru Lahir Nomor Dokumen : 01.04.01/801/2013 RSUD Badung:

1. Perawat di kamar bersalin mengambil bayi dan mengisi kartu identitas bayi baru lahir, baik lahir spontan ataupun tindakan.

2. Kartu yang sudah diisi lengkap ditempelkan pada status ibu.

3. Perawat memasang gelang identitas yang sudah lengkap pada kaki bayi dan tangan ibunya (warna sama) dengan ketentuan sebagai berikut:

- Perawat melengkapi sidik telapak kaki kiri dan kanan bayi serta sidik jari tangan kanan ibu pada lembar identifikasi (satu di rekam medis ibu, satu di rekam medis bayi) 
- Setelah bayi lahir, segera informasikan kepada suami atau keluarga dan perawat menyerahkan kartu identitas bayi untuk mencari status bayi ke rekam medis.

- Petugas loket memberikan cap stempel merah pada status bayi untuk bayi perempuan (karena semua status rawat inap warna biru).

- Perawat bertugas di kamar bersalin atau Ruang Operasi-Kebidanan agar melengkapi surat keterangan lahir yang ditandatangani oleh penolong diletakkan di daftar ibu.

- Perawat ruangan yang bertugas melengkapi administrasi menyerahkan surat keterangan lahir yang sudah lengkap pada saat pulang.

- Perawat senior menyerahkan bayi dan orang tua atau penanggung jawab menerima bayi, menandatangani lembar identifikasi bayi.

4. Para Staff RSU harus mengkonfirmasi identifikasi pasien dengan benar dengan menanyakan nama dan tanggal lahir pasien, kemudian membandingkannya dengan yang tercantum di dalam rekam medis dan gelang pengenal.

5. Pengecekan kesesuaian gelang dengan rekam medis dilakukan tiap kali ada pergantian jaga perawat.

6. Kewajiban dan tanggung jawab Perawat yang bertugas adalah bertanggungjawab memakaikan gelang identifikasi pasien dan memastikan kebenaran data yang tercatat di gelang pengenal"

"Standar Prosedur Operasional Pemasangan Gelang Pada Bayi Baru Lahir Rumah Sakit Umum Daerah Sanjiwani Nomor 188/11566/RSU/2015, yaitu:

1. Petugas menyiapkan gelang identitas bayi baru lahir saat mendampingi ibu dalam persalinan dan segera memasangkan gelang setelah bayi baru lahir.

2. Perawat menuliskan identitas bayi berupa nama ibu, tanggal lahir, gelang diberikan sesuai dengan jenis kelamin bayi (warna biru untuk bayi laki-laki, merah muda untuk bayi perempuan), bila ada tanda lahir tertentu maka dicatat dalam rekam medis pasien.

3. Gelang dipasangkan pada pergelangan tangan kanan, bila tidak memungkinkan dapat dipasangkan pada pergelangan tangan kiri, ataupun pada ekstremitas bawah seandainya pasien tidak memiliki ekstremitas atas.

4. Jika pasien tidak memiliki ekstremitas bawah dan atas maka identitas pasien dipasangkan pada dada dengan plester.

5. Perawat/ petugas meminta keluarga pasien untuk mendaftarkan bayi baru lahir ke bagian administrasi.

6. Perawat/ petugas memberi salam dan memperkenalkan bayi pada pasien.

7. Perawat menjelaskan maksud dan tujuan dari pemasangan gelang identitas bayi baru lahir.

8. Dalam waktu 24 jam perawat menambahkan nomor Rekam Medis bayi baru lahir pada gelang identitas bayi.

9. Perawat memberikan gelang tambahan pada ibu bayi sesuai dengan jenis kelamin bayi.

10.Perawat membubuhkan cap telapak kaki kanan dan kaki kiri bayi pada formulir Rekam Medis identifikasi Bayi baru lahir.

11.Perawat memastikan kembali identitas yang diberikan dan memastikan bahwa identitas masing-masing pasien telah benar.

12.Perawat/petugas melakukan monitoring terhadap gelang identitas pasien bayi. 
13.Gelang harus segera diganti jika terlepas sengaja karena alasan tertentu (misalnya tindakan invasive)."

Dari kedua Standar Prosedur Operasional di dua rumah sakit umum yang berbeda, terdapat kewajiban sebagai perawat maternitas yang berjaga, harus selalu mengecek kembali (monitoring) rekam medis pasien dan memastikan data yang telah ditulis oleh rekan kerja sebelumnya adalah benar. Jika Perawat Maternitas melakukan atau mengikuti tata cara Prosedur diatas dengan benar, Hal bayi tertukar tidak akan dapat terjadi, karena tujuan dari SPO dibuat adalah agar hal-hal seperti demikian tidak dapat terjadi. Pertanggungjawaban dapat dimintai secara internal atau eksternal.

Secara internal pelanggaran yang dilakukan oleh perawat dapat diselesaikan melalui pihak rumah sakit dengan mekanisme penyelesaian malpraktek perawat, hal ini didahului dengan laporan oleh pihak pasien/siapapun yang mengetahui adanya malpraktek perawat dengan pelanggaran kode etik/ SPO yang berlaku, lalu disampaikan kepada Ketua Komite Keperawatan secara tertulis/ lisan, Ketua Komite Keperawatan merekomendasikan kepada Sub Komite Etik dan Disiplin Profesi untuk melakukan kajian selama $2 \times 24$ jam setelah laporan diterima dan menentukan ada/tidaknya pelanggaran oleh perawat, setelah itu hasilnya akan dilaporkan kembali kepada Ketua Komite Keperawatan, dan Ketua Komite Keperawatan merekomendasikan hasil pengkajian kepada direktur rumah sakit, Direktur rumah sakit menentukan penegakan sanksi internal kepada perawat. Pertanggungjawaban perawat rumah sakit atas tindakan malpraktik yang dilakukan terhadap pasien adalah tunduk pada perjanjian kerja yang telah disepakati bersama antara perawat dengan rumah sakit. ${ }^{11}$

Dibawah ini akan dipaparkan tata cara identifikasi insiden misidentifikasi pasien Menurut Keputusan Direktur Rumah Sakit Umum Daerah Badung Nomor 326 Tahun 2012 tentang Identifikasi Pasien di Rumah Sakit, antara lain:

“Pelaporan Insiden/ Kejadian Kesalahan Identifikasi Pasien:

1. Setiap petugas yang menemukan adanya kesalahan identifikasi pasien harus segera melaporkan kepada perawat penanggungjawab pasien/ kepala ruangan di ruang gawat/departemen tersebut, kemudian melengkapi laporan insiden.

2. Petugas harus berdiskusi dengan Kepala Instalasi atau Manajemen mengenai pemilihan cara terbaik dan siapa yang memberitahukan kepada pasien atau keluarga mengenai kesalahan yang terjadi akibat kesalahan identifikasi.

3. Contoh kesalahan yang dapat terjadi adalah :

a. Kesalahan penulisan alamat di Rekam Medis;

b. Kesalahan informasi atau data di gelang pengenal;

c. Tidak adanya gelang pengenal di pasien;

d. Misidentifikasi data atau pencatatan di rekam medis;

e. Misdentifikasi pemeriksaan radiologi roentgen;

f. Misdentifikasi laporan investigasi;

11 Sari, S. P., \& Hasanah, U. (2015). Tinjauan Yuridis Terhadap Malpraktik Yang Dilakukan Oleh Perawat Pada Rumah Sakit Swasta (Analisis Dari Perspektif Hukum Perdata). Jurnal Online Mahasiswa Fakultas Hukum Universitas Riau. 2(1) 
g. Misdentifikasi perjanjian (appointment);

h. Registrasi ganda saat masuk rumah sakit;

i. Salah memberikan obat ke pasien;

j. Pasien menjalani prosedur yang salah;

k. Salah pelabelan indentitas pada sampel darah;

4. Kesalahan juga termasuk insiden yang terjadi akibat adanya misidentifikasi, dengan atau tanpa menimbulkan bahaya, dan juga insiden yang hampir terjadi di mana misidentifikasi terdeteksi sebelum dilakukan suatu prosedur.

5. Beberapa penyebab umum terjadinya misidentifikasi adalah :

a. Salah memberikan label

b. Kesalahan mengisi formulir

c. Kesalahan memasukkan nomor/ angka dalam rekam medis

d. Penulisan alamat yang salah

e. Pencatatan yang tidak benar/tidak lengkap/tidak terbaca

f. Setiap pelaporan insiden yang berhubungan dengan identifikasi pasien akan dipantau dan ditindaklanjuti".

Berdasarkan informasi yang didapatkan dari hasil wawancara yang dilakukan pada hari Selasa tanggal 31 bulan Mei tahun 2016 terhadap seorang perawat di Rumah Sakit Umum Sanjiwani Gianyar yang bernama Ni Putu Eka Asriyati, mengenai sanksi yang kemungkinan diberikan terhadap seorang perawat yang melakukan kesalahan sehingga salah memasang gelang berupa teguran lisan, namun jika melakukan kesalahan yang sama lagi akan dikenakan sanksi tertulis dan jika kesalahan tersebut sampai menimbulkan kerugian yang berat terhadap pasien, maka seorang perawat dapat di pecat dari rumah sakit dan dapat pula dicabut ijin nya oleh pemerintah.

Sedangkan secara eksternal, (pihak diluar Rumah Sakit) dapat dilakukan dengan cara melaporkannya kepada polisi agar perawat dapat dimintai pertanggungjawabannya secara Pidana bila melakukan malpraktik yang menyebabkan seorang bayi kehilangan identitasnya dengan dasar Pasal 277 KUHPidana: Barang Siapa dengan salah satu perbuatan sengaja menggelapkan asal-usul seseorang, diancam dengan pidana penjara paling lama enam tahun.

Perbuatan seseorang dapat dimasukkan dalam kategori criminal malpractice (Malpraktik Pidana) manakala perbuat tersebut memenuhi rumusan delik pidana yakni:

1. Perbuatan tersebut (positive act maupun negative act) merupakan perbuatan tercela;

2. Dilakukan dengan sikap batin yang salah (mensrea) yang berupa kesengajaan (intentional), kecerobohan (recklessness) atau kealpaan (negligence);

3. Criminal malpractice yang bersifat sengaja;

4. Criminal Malpractice yang bersifat ceroboh misalnya: melakukan tindakan medis tanpa persetujuan pasien (informed consent). ${ }^{12}$

Unsur Subjektif adalah unsur yang berasal dari dalam diri pelaku. Asas hukum pidana menyatakan tidak ada hukuman kalau tidak ada kesalahan. Kesalahan yang dimaksud

12 Sibagariang, E. E., \& Pusmaika, R. (2010). Kesehatan Reproduksi Wanita. Trans Info Media. Jakarta. h. 75. 
dalam hal ini adalah kesalahan yang dalam bentuk kesengajaan (intention/opzet/dolus) dan atau kealpaan (negligence or schuld).

1. Sikap batin adalah sesuatu yang ada di dalam batin sebelum orang berbuat. Sesuatu yang ada dalam batin ini dapat berupa pengetahuan, pikiran, perasaan, dan apapun yang melukiskan keadaan batin seseorang sebelum berbuat.

2. Kesalahan (kesengajaan/ Kealpaan) Sehubungan dengan hubungan batin antara si pembuat dan perbuatannya yang berisi menghendaki dan mengetahui, maka dalam ilmu hukum pidana terdapat teori kehendak dan teori membayangkan.

Teori membayangkan, adalah manusia hanya dapat mengkhendaki suatu tindakan, manusia tidak mengkhendaki suatu akibat atau membayangkan kemungkinan adanya suatu akibat. Sikap batin seorang perawat maternitas sepertinya cocok dengan teori membayangkan, dimana ketika tidak mengikuti salah satu prosedur yang merupakan ketentuan wajib bagi perawat maternitas sesuai dengan kompetensi kerjanya merupakan salah satu perbuatan sengaja untuk tidak melakukan sesuatu. Menurut teori ini perbuatan sengaja terdiri dari tiga jenis kesengajaan, salah satunya adalah teori membayangkan, dimana seseorang sudah dapat dikatakan sengaja melakukan sesuatu apabila ia telah mengkhendaki suatu tindakan namun tidak mengkhendaki suatu akibat.

Dalam hal ini perawat menghendaki suatu tindakan yaitu dengan tidak melakukan monitoring/ pengecekan kembali, namun Perawat tidak menghendaki terjadinya suatu akibat yaitu bayi ternyata tertukar. Jadi dapat dikatakan menurut teori ini, jika perawat dengan sengaja tidak melakukan suatu pelayanan dengan SPO dan mengakibatkan bayi tertukar meskipun tidak megkhendaki terjadi bayi tertukar, maka dapat dikatakan perbuatan perawat tersebut adalah perbuatan sengaja dan seharusnya dapat dimintai pertanggungjawabannya secara pidana.

Unsur objektif adalah unsur yang berasal dari luar diri pelaku yang terdiri atas:

1. Melawan hukum, Adapun perbuatan melawan hukum adalah apabila perbuatan itu bertentangan dengan hukum, yakni dengan larangan atau perintah. Pada konteks hukum pidana, menurut pendapat dari Satochid Kartanegara, "melawan hukum" (Wederrechtelijk) dalam hukum pidana dibedakan menjadi:

a) Wederrechtelijk formil, yaitu apabila sesuatu perbuatan dilarang oleh undangundang. Seorang perawat diharuskan mengikuti Standar Prosedur Operasional dalam melakukan setiap tindakan atau upaya hukum. Hal ini dengan tegas diatur dalam Pasal 24 UU Kesehatan yang menyatakan bahwa setiap tenaga kesehatan harus melakukan upaya kesehatan sesuai dengan Standar Prosedur Operasional, hal ini juga diatur dalam Pasal 1 angka (14) UU Tenaga Kesehatan dimana "Standar Prosedur Operasional adalah suatu perangkat instruksi / langkah-langkah yang dibakukan untuk menyelesaikan proses kerja rutin tertentu dengan memberikan langkah yang benar dan terbaik berdasarkan konsensus bersama untuk melaksanakan berbagai kegiatan dan fungsi pelayanan yang dibuat oleh Fasilitas Pelayanan Kesehatan berdasarkan Standar Profesi."

b) Wederrechtelijk Materiil, yaitu sesuatu perbuatan "mungkin" wederrechtelijk, walaupun tidak dengan tegas dilarang dan diancam dengan hukuman oleh undang-undang. Melainkan juga asas-asas umum yang terdapat di dalam lapangan hukum (algemen beginsel). Sudah suatu hal yang umum diketahui 
masyarakat bahwa setiap tenaga kesehatan (perawat) dalam melakukan setiap tindakan yang berhubungan dengan keselamatan dan keamanan pasien dilakukan dengan mengikuti standar prosedur operasional untuk menjamin keselamatan dalam melakukan upaya kesehatan.

2. Akibat (result) tersebut membahayakan atau merusak, bahkan menghilangkan kepentingan-kepentingan yang dipertahankan oleh hukum, misalnya nyawa, badan, kemerdekaan, hak milik, kehormatan, dan lainnya. Akibat yang ditimbulkan adalah hilangnya identitas seorang bayi, merupakan hal atau akibat yang dilarang dalam Pasal 277 KUHP dan juga dalam Pasal 14 UU Perlindungan Anak yang menyatakan bahwa setiap anak (dalam hal ini termasuk bayi) memiliki hak untuk diasuh oleh orang tuannya sendiri. Adanya Akibat Kerugian dari sudut hukum pidana, akibat yang merugikan masuk dalam lapangan pidana apabila jenis kerugian disebut dalam rumusan kejahatan. ${ }^{13}$ Kesengajaan yang dilakukan oleh perawat maternitas dalam hal tidak mengikuti prosedur identifikasi bayi baru lahir yaitu keharusan melakukan pengecekan kembali pada identitas bayi yang telah terpasang pada gelangnya yang mana jika hal ini tidak dilakukan maka aka nada kemungkinan seorang bayi tertukar dengan bayi yang lain, maka sesungguhnya seorang perawat telah melakukan penggelapan terhadap asal-usul bayi. Hal ini merupakan akibat yang dilarang oleh Pasal 277 KUHP, Pasal 14 UU Perlindungan Anak. Penjelasan mengenai Pasal 277 KUHP adalah: mengenai "salah satu perbuatan sengaja" adalah Perbuatan-perbuatan yang sengaja sehingga asal-usul (kelahiran) seseorang menjadi tidak tentu misalnya anak tertukar, menyembunyikan, memungut, atau suatu keadaan dimana dikatakan seorang anak lahir dari iu yang berbeda dengan ibu sesungguhnya. ${ }^{14}$

3. Sifat dapat dihukum berkenaan dengan alasan-alasan yang membebaskan si pelaku dari hukuman, misalnya tidak cakap secara hukum. Sifat dapat dihukum: seorang perawat maternitas memiliki kualifikasi untuk dapat bertanggungjawab karena tidak ada alasan pembenar maupun alasan pemaaf yang dimilikinya, bukan melakukan kesalahan atas dasar perintah atasan ataupun dengan kondisi jiwa yang tidak sehat.

\section{Kesimpulan}

Terdapat tugas utama sebagai perawat maternitas yang berjaga pada saat melakukan asuhan terhadap bayi baru lahir yang mana tidak dimiliki oleh perawat lain, yaitu harus selalu mengecek kembali (monitoring) rekam medis pasien dan memastikan data yang telah ditulis oleh rekan kerja sebelumnya mengenai identitas seorang bayi adalah benar. Jika Perawat Maternitas melakukan atau mengikuti tata cara Prosedur Operasional, maka hal bayi tertukar tidak akan dapat terjadi, karena tujuan dari SPO dibuat adalah agar hal-hal seperti demikian tidak dapat terjadi. Terdapat dua Standar Prosedur Operasional dari dua rumah sakit umum yang berbeda, dimana dengan tegas menyatakan bahwa terdapat kewajiban sebagai perawat maternitas yang berjaga, harus selalu mengecek kembali (monitoring) rekam medis pasien (bayi) dan memastikan data yang telah ditulis oleh rekan kerja sebelumnya adalah benar. Jika Perawat Maternitas tidak melakukan atau mengikuti tata cara Prosedur dengan benar, Maka Pertanggungjawaban dapat dimintai secara internal atau eksternal.

13 Triwibowo, C. (2010). Hukum Keperawatan. Pustaka Book Publisher. Yogyakarta. h. 273.

14 Soesilo. R. Op.Cit. h. 202 
Secara internal pelanggaran yang dilakukan oleh perawat yaitu melalui pihak rumah sakit dengan mekanisme penyelesaian malpraktek perawat, hal ini diatur dengan Tata Cara Identifikasi Insiden Missidentifikasi Pasien Menurut Keputusan Direktur Rumah Sakit Umum Daerah Badung Nomor 326 Tahun 2012 tentang Identifikasi Pasien di Rumah Sakit, terdapat sanksi yang diberikan terhadap seorang perawat yang melakukan kesalahan sehingga salah memasang gelang berupa teguran lisan, namun jika melakukan kesalahan yang sama lagi akan dikenakan sanksi tertulis dan jika kesalahan tersebut sampai menimbulkan kerugian yang berat terhadap pasien, maka seorang perawat dapat di pecat dari rumah sakit dan dapat pula dicabut ijin nya oleh pemerintah.

secara eksternal, (pihak diluar Rumah Sakit) dapat dilakukan dengan cara melaporkannya kepada polisi agar perawat dapat dimintai pertanggungjawabannya secara Pidana bilamana telah melakukan malpraktik yang menyebabkan seorang bayi kehilangan identitasnya dengan dasar Pasal 277 KUHPidana.

Unsur Subjektif adalah unsur yang berasal dari dalam diri pelaku: 1. Sikap batin adalah sesuatu yang ada di dalam batin sebelum orang berbuat (apakah perawat memang berniat untuk tidak mengikuti standar prosedur operasional 2. Kesalahan (kesangajaan/ Kealpaan) Sehubungan dengan hubungan batin antara si pembuat dan perbuatannya yang berisi menghendaki dan mengetahui, kesengajaan yang salah satunya dapat ditafsirkan dengan adalah teori kesengajaan dengan membayangkan dimana seseorang sudah dapat dikatakan sengaja melakukan sesuatu apabila ia telah menghendaki suatu tindakan (tidak mengikuti standar prosedur operasional yaitu pengecekan ulang terhadap identitas gelang bayi) namun tidak mengkhendaki suatu akibat (bayi tertukar).

Unsur objektif adalah unsur yang berasal dari luar diri pelaku yang terdiri atas: 1 . Melawan hukum, Adapun perbuatan melawan hukum adalah apabila perbuatan itu bertentangan dengan hukum yaitu Pasal 24 UU Kesehatan yang menyatakan bahwa setiap tenaga kesehatan harus melakukan upaya kesehatan sesuai dengan Standar Prosedur Operasional. 2. Akibat (result) tersebut membahayakan atau merusak, bahkan menghilangkan kepentingan-kepentingan yang dipertahankan oleh hukum Akibat yang ditimbulkan adalah hilangnya identitas seorang bayi, merupakan hal atau akibat yang dilarang dalam Pasal 277 KUHP dan juga dalam Pasal 14 UU Perlindungan Anak yang menyatakan bahwa setiap anak (dalam hal ini termasuk bayi) memiliki hak untuk diasuh oleh orang tuannya sendiri. 3. Dapat dihukum, dapat dihukum berkenaan dengan alasan-alasan yang membebaskan si pelaku dari hukuman. Misalnya tidak cakap secara hukum. Seorang perawat tidak memiliki kualifikasi alasanpemaaf maupun pembenar, makai a memenuhi unsur dapat dihukum.

Unsur-unsur diatas telah terpenuhi maka seorang perawat maternitas yang dengan sengaja tidak mengikuti standar prosedur operasional rumah sakit sehingga mengakibatkan identitas seorang bayi menjadi hilang dapat dimintai pertanggungjawabannya secara pidana yang berdasarkan Pasal 277 KUHPidana dan dapat dipidana penjara paling lama 6 tahun. 


\section{Daftar Pustaka}

\section{Buku}

Amirudin, A., \& Asikin, Z. (2010). Pengantar Metode Penelitian Hukum. Rajawali Pers. Jakarta.

Masrudi, M. (2016). Etika Profesi dan Hukum Kesehatan. Pustaka Baru Press. Yogyakarta.

Nugroho, H. W. (2009). Komunikasi dalam keperawatan gerontik. EGC.

Dermawan, D. (2013). Pengantar keperawatan profesional. Yogyakarta: Gosyen Publishing.

Sibagariang, E. E., \& Pusmaika, R. (2010). Rismalinda. Kesehatan reproduksi wanita Jakarta: Trans Info Media.

Soedjono, D. (2004). Pengantar Ilmu Hukum, Jakarta: PT. Raja Grafindo Persada.

Soesilo, R. (1996). KUHP serta komentar-komentarnya. Bogor: Politeia

Triwibowo, C. (2010). Hukum Keperawatan. Yogyakarta: Pustaka Book Publisher.

\section{Jurnal}

Merdekawati, Y. (2013). Tanggung Jawab Pidana Perawat Dalam Melakukan Tindakan Keperawatan Berdasarkan Undang-Undang Nomor 36 Tahun 2009 Tentang Kesehatan (Studi Di Rumah Sakit Umum Santo Antonius Pontianak). Jurnal Nestor Magister Hukum. 3(5)

Oktaria, G., \& Awza, R. (2017). Komunikasi Terapeutik Perawat dalam Proses Penyembuhan Pasien Psikosis di Upt. Bina Laras Provinsi Riau. Jurnal Online Mahasiswa Fakultas Ilmu Sosial dan Ilmu Politik Universitas Riau. 4(2). 1-15

Sari, S. P., \& Hasanah, U. (2015). Tinjauan Yuridis Terhadap Malpraktik Yang Dilakukan Oleh Perawat Pada Rumah Sakit Swasta (Analisis Dari Perspektif Hukum Perdata). Jurnal Online Mahasiswa Fakultas Hukum Universitas Riau, 2(1). 1-14.

Siti, M., Zulpahiyana, Z., \& Indrayana, S. (2016). Komunikasi Terapeutik Perawat Berhubungan dengan Kepuasan Pasien. Jurnal Ners dan Kebidanan Indonesia. 4(1) 30-34. http://dx.doi.org/10.21927/jnki.2016.4(1).30-34

Tampubolon, Susi Natalia. (2013). Pertanggungjawaban Rumah Sakit Terhadap Tindak Pidana Malpraktek. Jurnal Departemen Hukum Pidana.

Tampubolon, S. N. (2013). Pertanggungjawaban Pidana Rumah Sakit Terhadap Tindak Pidana Malpraktek. Jurnal Departemen Hukum Pidana.

Yularsih, D. (2014). Penerapan Komunikasi Terapeutik pada Proses Penyembuhan Pasien di Bangsal Keperawatan RSUD Kota Semarang. Jurnal The Messenger. 6(2). 8-16. 


\section{Peraturan Perundang-undangan}

Kitab Undang-Undang Hukum Pidana

Undang-Undang Nomor 35 Tahun 2004 tentang Perubahan terhadap Undang-Undang Nomor 23 Tahun 2002 Tentang Perlindungan Anak, Tambahan Lembaran Negara Republik Indonesia Nomor 4235

Undang-Undang Nomor 44 Tahun 2009 Tentang Rumah Sakit (Lembaran Negara Republik Indonesia Tahun 2009 Nomor 144, Tambahan Lembaran Negara

Undang-Undang Nomor 36 Tahun 2014 tentang Tenaga Kesehatan (Lembaran Negara Republik Indonesia Tahun 2014 Nomor 208, Tambahan Lembaran Negara Republik Indonesia Nomor 5607

Undang-Undang Nomor 38 Tahun 2014 Tentang Keperawatan Tambahan Lembaran Negara Republik Indonesia Nomor 5612

Peraturan Menteri Kesehatan Nomor 148 Tahun 2010 Tentang Izin Dan Penyelenggaraan Praktik Perawat

Standar Operasional Prosedur Pemberian Gelang pada Bayi Baru Lahir Nomor Dokumen : 01.04.01/801/2013 RSUD Badung

Standar Prosedur Operasional Pemasangan Gelang Pada Bayi Baru Lahir Rumah Sakit Umum Daerah Sanjiwani Nomor 188/11566/RSU/2015

Keputusan Direktur Rumah Sakit Umum Daerah Badung Nomor 326 Tahun 2012 tentang Identifikasi Pasien di Rumah Sakit 